УДК 342.951: 629.82

DOI https://doi.org/10.32849/2663-5313/2020.5.27

\title{
Олександр Чумак,
}

докт. юрид. наук, заслужений юрист Украӥни,

заступник начальника з економічної та адміністративно-фінансової роботи

Льотної академіі

Національного авіаційного університету

\section{АДМІНІСТРАТИВНА ВІДПОВІДАЛЬНІСТЬ ПАСАЖИРІВ У ГАЛУЗІ ЦИВІЛЬНОЇ АВІАЦІї: ПОРІВНЯЛЬНО-ПРАВОВИЙ АНАЛІЗ}

У статті здійснено порівняльний аналіз адміністративної відповідальності пасажирів у галузі иивільної авіаиії. Проаналізовано особливості провадження у справах про адміністративні правопорушення відносно пасажирів авіаиійного транспорту. Наголошено на важливості обставин початку адміністративного розслідування та подальших адміністративних проваджень. Визначено наявність ознак адміністративного проступку в діях особи. Під час вивчення органів, наділених повноваженнями державного контролю в иивільній авіаиії, з'ясовано приниип суб'єктивізму під час їх формування. Запропоновано посилити відповідальність міжнародних польотних пасажирів, передбачену чинною нормативно-правовою базою. Виділено особливості стадій адміністративного судочинства. Більш глибока експертиза проводиться до стадії судових виконавчих дій в адміністративній справі. Запропоновано збільшення відповідальності пасажирів літака міжнародного сполучення, передбаченої чинним КУпАП. Визначено особливості стадій адміністративного провадження. Зроблено висновок про те, що до ознак адміністративної відповідальності належать підстава адміністративної відповідальності, тобто скоєння правопорущення, в галузі иивільної авіації; відносини, внаслідок яких настає адміністративна відповідальність, що регламентується нормами підзаконних актів, спечіальних законодавчих актів, міжнародних угод у галузі иивільної авіації; загальнообов'язковий, публічний характер адміністративної відповідальності (фактично відбувається ї̈ поширення на всій території Украйни); обмежене, визначене коло суб'єктів, що можуть накладати адміністративні стягнення; те, що суб'єктами адміністративної відповідальності є юридичні та фізичні особи; особливий порядок притягнення до адміністративної відповідальності (залежно від суб'єктів); спечифічна сфера впливу, а саме иивільна авіачія, що обумовлює свої особливості. Сьогодні доцільно підвищити розмір санкцій, передбачених статтею 112 КУпАП.

Ключові слова: цивільна авіація, авіаційний транспорт, пасажир, пасажир з обмеженими можливостями, провадження в справі про адміністративні правопорушення.

Постановка проблеми. Велике значення сьогодні має адміністративна відповідальність пасажира в галузі цивільної авіації. Стрімкий розвиток авіаційної галузі, науково-технічний прогрес привели до підвищення кількості правопорушень у галузі цивільної авіації. Зазначене приводить до необхідності правового регулювання адміністративної відповідальності галузі цивільної авіації.

Питання дослідження адміністративної відповідальності висвітлені в працях В.В. Іщенка, І.П. Голосніченка, М.Ф. Стахурського, І.О. Картузова, Н.П. Матюхіна, С.М. Алфьорова, С.В. Ващенка, М.М. Долгополової та інших учених-правників.

Метою статті $є$ аналіз адміністративної відповідальності пасажирів у галузі цивільної авіації.
Виклад основного матеріалу. Повітряним кодексом України передбачено, що авіаційна безпека - це захист цивільної авіації від актів незаконного втручання, який забезпечується комплексом заходів із залученням людських і матеріальних ресурсів.

В Повітряному кодексі міститься таке визначення терміна «пасажир»: фізична особа, яка перевозиться повітряним судном за згодою перевізника відповідно до договору перевезення, крім членів екіпажу та додаткових спеціалістів на борту повітряного судна, працівників експлуатанта повітряного судна, уповноваженого представника відповідного національного органу регулювання та осіб, які супроводжують вантаж.

Пасажир з обмеженими фізичними можливостями або особа 3 інвалідністю - це пасажир, рухливість якого під час використання транспортного засобу є обмеженою 
внаслідок фізичної (сенсорної або опорнорухової, постійної або тимчасової) чи розумової недієздатності або з будь-якої іншої причини, зокрема через похилий вік, стан якого потребує відповідної уваги та пристосування до його особливих потреб під час обслуговування пасажирів [1].

Для дослідження відповідальності пасажира в галузі цивільної авіації пропонуємо проаналізувати адміністративне провадження в галузі цивільної авіації.

Адміністративне провадження в галузі цивільної авіації, як, зокрема, провадження в справах про адміністративні правопорушення, майже не досліджувалось.

На думку В.В. Іщенка, І.П. Голосніченка, М.Ф. Стахурського, І.О. Картузова, Н.П. Матюхіна, слід виділити п'ять таких стадій провадження в справах про адміністративні правопорушення: порушення справи; адміністративне розслідування; розгляд справи та її вирішення; перегляд постанови; виконання постанови [1, с. 45].

Порушником законодавства в галузі цивільної авіації, згідно з КУпАП, є фізична особа.

Важливим в адміністративному провадженні є момент початку адміністративного розслідування. Слід відзначити, що КУпАП та інші акти національного законодавства не визначають, з якого моменту адміністративне провадження є розпочатим [3].

КУПАП визначає тільки обставину, за якої адміністративне провадження порушується, а саме наявність в діях особи ознак адміністративного проступку. КУпАП визначає що такі дані встановлюються особами, уповноваженими складати протокол про адміністративне правопорушення (стаття 255 КУ ПАП); особами, що вживають заходів забезпечення провадження у справах про адміністративні правопорушення (стаття 260 КУпАП), а саме адміністративне затримання особи, особистий огляд, огляд речей, вилучення речей і документів; особою, яка уповноважена здійснювати доставлення порушника (стаття 259 КУ ПАП); особою, яка уповноважена накладати стягнення на місці вчинення правопорушення без складання протоколу (стаття 258 КУпАП). Цей перелік $\epsilon$ неповним.

Варто зазначити, що провадження в адміністративних справах відносно фізичних осіб відбувається в межах, визначених КУПАП. Водночас ця процедура регулюється низкою підзаконних актів, які не повинні суперечити КУ ПАП

Порядок провадження у справах про адміністративні правопорушення на авіаційному транспорті регламентується Наказом
Міністерства інфраструктури «Про затвердження Порядку накладення і стягнення штрафів за порушення вимог законодавства на повітряному транспорті» від 26 грудня 2011 р. № 637 [4]. Варто зазначити, що дія зазначеного Порядку поширюється на суб'єктів авіаційної діяльності в разі здійснення ними правопорушення у галузі цивільної авіації та фізичних осіб у разі здійснення ними адміністративного правопорушення на повітряному транспорті.

Варто відзначити, що аналіз органів, що здійснюють державний контроль у галузі цивільної авіації, обумовлює суб'єктний склад органів, уповноважених здійснювати адміністративне провадження й, відповідно, складати протоколи про адміністративне правопорушення в галузі цивільної авіації.

До осіб, що мають право складати протокол про вчинення правопорушення в галузі цивільної авіації, слід віднести голову Державної авіаційної служби України, заступників голови Державної авіаційної служби України, посадових осіб Державіаслужби України, керівників аеропортів, начальників служб авіаційної безпеки аеропортів та їх заступників, судові інстанції.

Визначальними ознаками цієї стадії $€$ момент початку адміністративного провадження, встановлення факту правопорушення, особи порушника, потерпілих, законність, тривалість, складання протоколу, вирахування розміру завданої шкоди (у передбачених законом випадках збитків).

Другою стадією $є$ розгляд справи про адміністративне правопорушення в галузі цивільної авіації та винесення щодо неї постанови.

Згідно зі статтею 278 КУпАП перед початком безпосереднього розгляду справи орган, посадова особа уповноважені здійснювати розгляд справи, проводять перевірку зібраних матеріалів. Метою цієї перевірки $€$ вирішення таких питань:

1) чи належить до компетенції цього органу, посадової особи розгляд цієї справи;

2) чи правильно складено протокол та інші матеріали справи про адміністративні правопорушення;

3) чи сповіщено осіб, які беруть участь у розгляді справи, про час і місце її розгляду;

4) чи витребувано необхідні додаткові матеріали;

5) чи підлягають задоволенню клопотання особи, яка притягається до адміністративної відповідальності, потерпілого, їх законних представників та адвоката.

Варто зазначити, що орган, посадова особа, що розглядають справу, зобов’язані перевірити якість складання протоколу. Орган, посадова особа, що здійснюють 
розгляд справи про порушення в галузі цивільної авіації, не мають права приймати до провадження такі з них, що складені неохайно або 3 порушенням вимог чинного законодавства. В разі виявлення таких недоліків орган, посадова особа, що розглядають справу, повертають матеріали на доопрацювання або повторне репродукування. Неповні або суперечні матеріали також повертаються на доопрацювання. Інакше вони фактично є незаконними і будуть такими визнані.

Питання розгляду справи регулюється нормами КУпАП, Митного кодексу, інших підзаконних нормативно-правових актів в галузі цивільної авіації.

Слід зазначити, що законодавством встановлений 15-денний строк розгляду справ щодо порушення в галузі цивільної авіації 3 дня одержання Державіаслужбою України протоколу про правопорушення. Таким чином, можна дійти висновку, що цей порядок за своїм характером більше стосується саме юридичних осіб. Штраф може бути накладено на юридичну особу - суб'єкта авіаційної діяльності протягом шести місяців 3 дня виявлення правопорушення, але не пізніше ніж через три роки з дня його вчинення

У разі вчинення юридичною особою - суб'єктом авіаційної діяльності двох або більше правопорушень штрафи накладаються за кожне вчинене правопорушення окремо.

Не менш важливою є стадія виконання прийнятого рішення або постанови щодо адміністративної справи. Ця стадія є дуже важливою. Фактично виконання постанови передбачає не тільки власне виконання постанови суду або державного компетентного органу. Виконання постанови здійснюється відповідно до Закону України «Про виконавче провадження в Україні», КУ ПАП, зазначеного порядку.

Таким чином, особливостями провадження у справах про адміністративні правопорушення в авіаційній галузі $€$ момент початку адміністративного розслідування; суб'єкт правопорушення; специфічний об'єкт, а саме відносини в галузі транспорту.

Цивільна авіація є досить новим напрямом транспортної інфраструктури, що обумовлює свої особливості правопорушень та відповідальності взагалі.

Варто відзначити, що досі питання дослідження складів адміністративних правопорушень у юридичній літературі практично не досліджувались. Як зазначають М.С. Кельман та Р.Г. Мурашин, адміністративна відповідальність - це специфічний вид відносин між державою, її органами, службовими особами (представниками цих органів) та особами (фізичними, юридичними особами, організаціями, винними у порушенні норм права). Зміст цих відносин складає юридичний факт, а саме вчинення правопорушення [1, с. 351].

Варто відзначити, що сьогодні в юридичній науці не сформовано однозначного визначення адміністративної відповідальності. Так, на думку Ю.С. Шемшученка, адміністративну відповідальність слід визначати як застосування адміністративних покарань уповноваженими на те органами до громадян і посадових осіб за порушення норм природоохоронного законодавства [2, с. 300].

На думку С.М. Алфьорова, С.В. Ващенка, М.М. Долгополової, адміністративній відповідальності як різновиду юридичної відповідальності притаманні такі ознаки:

1) має зовнішній характер;

2) застосовується лише за вчинення правопорушення;

3) пов’язана 3 державним примусом у формах каральних і правовідновлювальних заходів;

4) визначена у нормах права;

5) притягнення правопорушника до відповідальності здійснюється в певному процесуальному порядку;

6) притягнення до відповідальності здійснюється уповноваженими державними органами та посадовими особами;

7) винна у вчиненні правопорушення особа несе певні втрати матеріального та побутового характеру, які передбачені законом.

Статтею 9 КУпАП визначено, що Адміністративним правопорушенням (проступком) визнається протиправна, винна (умисна або необережна) дія чи бездіяльність, яка посягає на громадський порядок, власність, права й свободи громадян, на встановлений порядок управління і за яку законом передбачено адміністративну відповідальність.

Ознаками адміністративної відповідальності в галузі цивільної авіації є такі:

- підстава адміністративної відповідальності, тобто скоєння правопорушення, в галузі цивільної авіації;

- відносини, внаслідок яких настає адміністративна відповідальність, що регламентується нормами підзаконних актів, спеціальних законодавчих актів, міжнародних угод у галузі цивільної авіації;

- загальнообовязковий, публічний характер адміністративної відповідальності (фактично відбувається її поширення на всій території України);

- обмежене, визначене коло суб'єктів, що можуть накладати адміністративні стягнення; 
- суб'єктами адміністративної відповідальності є юридичні та фізичні особи;

- особливий порядок притягнення до адміністративної відповідальності (залежно від суб'єктів);

- специфічна сфера впливу, а саме цивільна авіація, що обумовлює свої особливості [5, с. 121].

Адміністративна відповідальність пасажира на авіаційному транспорті передбачена статтею 112 КУПАП. Так, частиною 1 статті 112 КУпАП визначено, що невиконання особами, які перебувають на повітряному судні, розпоряджень командира судна тягне за собою попередження або накладення штрафу від двадцяти до двохсот неоподатковуваних мінімумів доходів громадян. Частиною 2 зазначеної статті передбачено, що порушення правил фотографування, кінозйомки й користування засобами радіозв’язку з борту повітряного судна тягне попередження або накладення штрафу від двадцяти до трьохсот неоподатковуваних мінімумів доходів громадян. Однак протиправна поведінка пасажира на борту повітряного судна, може призвести до порушення вимог безпеки польотів, що є недопустимим, і становитиме загрозу для інших пасажирів та членів екіпажу, тому доцільним сьогодні $€$ підвищення розміру санкцій, передбачених статтею 112 КУПАП.

\section{Висновки}

До ознак адміністративної відповідальності належать підстава адміністративної відповідальності, тобто скоєння правопорушення, в галузі цивільної авіації; відносини, внаслідок яких настає адміністративна відповідальність, що регламентується нормами підзаконних актів, спеціальних законодав- чих актів, міжнародних угод у галузі цивільної авіації; загальнообовязковий, публічний характер адміністративної відповідальності (фактично відбувається її поширення на всій території України); обмежене, визначене коло суб'єктів, що можуть накладати адміністративні стягнення; те, що суб'єктами адміністративної відповідальності є юридичні та фізичні особи; особливий порядок притягнення до адміністративної відповідальності (залежно від суб'єктів); специфічна сфера впливу, а саме цивільна авіація, що обумовлює свої особливості. Сьогодні доцільно підвищити розмір санкцій, передбачених статтею 112 КУ ПАП.

\section{Список використаних джерел:}

1. Повітряний кодекс України. Кодекс України, Закон, Кодекс від 19 травня 2011 р. № 3393-VI. Відомості Верховної Ради України (ВВР). 2011. № 48-49. Ст. 536.

2. Битяк Ю.П., Гаращук В.М., Дьяченко О.В та ін. Адміністративне право України : підручник. Київ : Юрінком Інтер, 2005. 544 с.

3. Кодекс України про адміністративні правопорушення. Кодекс від 7 грудня 1984 р. № 8073-Х. Відомості Верховної Ради Украйнськоі РСР (ВВР). 1984. Додаток до № 51. Ст. 1122.

4. Про затвердження Порядку погодження місця розташування та висоти об'єктів на приаеродромних територіях та об'єктів, діяльність яких може вплинути на безпеку польотів і роботу радіотехнічних приладів цивільної авіації : Наказ Міністерства інфраструктури від 30 листопада 2012 р. № 721, зареєстрованого в Міністерстві юстиції України 24 грудня 2012 р. № 2147/22459. URL: http://zakon3.rada.gov.ua/laws/show (дата звернення: 01.09.2016)

5. Москаленко С.I. Державне регулювання діяльності цивільної авіації в Україні : монографія. Кропивницький : ЛА НАУ, 2018, 320 с.

The article makes a comparative analysis of the administrative responsibility of passengers in the field of civil aviation. The author analyzes peculiarities of proceedings in cases of administrative offenses against passengers of aviation transport. The importance of the circumstances of the initiation of the administrative inquiry and of the further administrative proceedings was emphasized. The presence of signs of administrative misconduct in the actions of a person was determined. It was found that in the course of studying the bodies vested with the powers of state control in civil aviation, we learned the principle of subjectivism in their formation. The author proposes to increase the responsibility of international flight passengers provided by the current legal framework. The features of the stages of administrative proceedings are highlighted. A deeper examination is carried out to the stage of administrative enforcement actions in an administrative case. It is proposed to increase the liability of the passengers of the aircraft of the international service, stipulated by the existing Code of Administrative Offenses. The peculiarities of the stages of administrative proceedings are identified. It is concluded that the attributes of administrative responsibility include: 1) the basis of administrative responsibility, i.e. the commission of an offense, in the field of civil aviation; 2) the relations which result in administrative responsibility are regulated by the norms of by-lawes, special legislative acts, international agreements in the field of civil aviation; 3) obligatory, public nature of administrative responsibility. In fact, its spread throughout Ukraine; 4) a limited, defined range of entities that may impose administrative penalties; 5) legal and natural persons are subjects of administrative responsibility; 6) defined, special procedure for bringing to administrative responsibility (depending on the subjects); 7) specific sphere of influence - civil aviation, which determines its peculiarities. Today, it is advisable to increase the sanctions provided for in Article 112 of the Code of Administrative Offenses.

Key words: civil aviation, air transport, passenger, disabled passenger, proceedings in administrative misdemeanors. 